\title{
The twilight of the separation of powers: Proportionality as a method of solving institutional issues
}

\author{
MARTIN HAPLA* (1)
}

Faculty of Law, Department of Legal Theory, Masaryk University, Brno, Czech Republic

\section{ORIGINAL RESEARCH PAPER}

Received: February 18, 2019 • Revised manuscript received: August 14, 2020 - Accepted: October 13, 2020

Published online: June 8, 2021

(C) 2020 Akadémiai Kiadó, Budapest

\section{ABSTRACT}

The author examines the tension that exists between the various components of the separation of powers (in particular the ideas of independence and separation, and the system of checks and balances). He analyses different ways of solving them. Attention is paid, for example, to attempting to supplement the separation of powers with some other normative thesis. The author rejects previous approaches and argues that the components of the separation of powers can be understood as separate principles. Conflicts between these principles should be resolved through proportionality.

\section{KEYWORDS}

separation of powers, system of checks and balances, proportionality, legitimacy of judicial decision making, constitutional theory

\section{INTRODUCTION}

The separation of powers is undoubtedly one of the traditional themes of constitutional and political theory. In recent years, however, its exploration has become more and more important, especially as many liberal democracies have been weakening in many parts of the world.

\footnotetext{
*Corresponding author. E-mail: Martin.Hapla@law.muni.cz
} 
Particularly in Central Europe, a number of constitutional systems are undergoing major changes, for example, in regard to the status of their judiciaries. ${ }^{1}$ Attention is paid not only to specific changes in the countries most affected by these trends but also to the general starting points of the whole issue. What is the separation of powers, exactly? Does it really contain any clues to assist us in our reflections on the institutional organization of the state? And are we even able to recognize such clues? These are just a few examples of the many questions that we can raise in this context. However, the key general issue of this text has emerged from some of the specific problems that have arisen - and are currently manifest - in the Central European space. For example, the Constitutional Court in the Czech Republic has had to deal with cases concerning whether the President of the Republic may appoint as deputy chairman of the Supreme Court any judge, or only a judge of that court. ${ }^{2}$ The background to this question was the contradiction between the requirements of independence and the system of checks and balances. The Constitutional Court did not perceive this contradiction. It only identified the requirements of independence with the principle of the separation of powers, justifying that such a procedure by the President of the Republic is not possible. ${ }^{3}$ One of the aims of this paper is to avoid similar decisions that lack transparency. The aim is to provide a better alternative to such decision-making.

In the current literature, the separation of powers is sometimes characterized as a legal, and sometimes as a political, principle. These characteristics reflect the specifics of various constitutional systems. ${ }^{4}$ In this text we will consider it in particular from the perspective of the constitutional court, which is forced to solve the various subtle problems of the institutional arrangement of the state. We will, therefore, perceive it as the legal principle which we expect to provide us with clues to solving practical cases. This aspect seems to be the most important in the Central European context because the basic parameters of the local constitutional system were set many years ago; and in practice there are several more sophisticated problems, which in the end must usually be resolved within the constitutional courts. This, of course, is not to deny the significance of different points of view; for example, the constitutionalist perspective of the democratic rule-of-law, which in the light of this principle seeks guidance on how to set the relations between state bodies in the new constitution. As I will try to show in the following text, some of the conclusions presented here go beyond the initial perspective of the way in which constitutional courts deal with practical cases.

After this clarification, we can now raise the initial question: is the separation of powers capable of being a principle in the above-mentioned sense? If it is to be relevant as a principle, it must provide guidance for institutional applications in specific cases that are consistent, even over a longer time frame. This is not to deny the obvious fact that in practice people often behave irrationally, are not sufficiently informed, and are subject to their personal interests, and for these

\footnotetext{
${ }^{1}$ The issue of the decline of liberal democracy in Central Europe and the separation of powers is explored by the interesting text by Pavel Dufek, Jiří Baroš and David Kosař. Baroš, Dufek and Kosař (2018).

${ }^{2}$ Czech Republic Constitutional court Judgment of 12 September 2007 n. Pl. ÚS 87/06 (2007) link 1.

${ }^{3}$ By choosing a case from Czech law, I do not wish to claim that this question is important especially for this country. I attribute to it broader relevance and I chose the Czech case mainly because it illustrates very well the problems analysed in this article.

${ }^{4}$ In some countries, the separation of powers is more likely to be understood as a legal principle (e.g. Germany), in others as a political mechanism (e.g. the USA). Möllers (2013) 50. For the separation of powers as a legal principle and for the principle of political theory in the US context, compare also Waldron (2016) 46-48.
} 
and other reasons they do not agree with such applications. It is argued here that if we could shade these negative phenomena and take into account ideal individuals in an ideal situation, then such people would agree in the long-term on the principle of the separation of powers in individual cases. In other words, if the separation of powers is to be a principle, it must at least have the potential to provide us with consistent solutions over a longer period of time. Because if nothing could really be inferred from it, or almost anything could be deduced from it, it would easily open the door to arbitrary decision-making. It would rather be a magical hat from which anyone can pull what they want. It would not be a real principle because it would not provide us with the reasons for dealing with cases but would rather hide the real reasons.

In this text, the thesis will be defended that the separation of powers is not a principle in the sense in question, nor can it be. By this I mean that it is not normative; we cannot deduce from it how we should proceed in one situation or another. Contemporary doctrine recognizes that it is composed of several diverse components, for which different authors try to find a suitable essential element. I think such an effort is futile. There is insurmountable tension between these components (in particular between institutional independence and the system of checks and balances), and it is therefore more appropriate to understand them as separate principles that can collide. The existing theories of the separation of powers are unable to provide transparent methods by which these collisions can be resolved. In the following pages, it will be suggested that the appropriate way to solve them is to use a certain variant of the proportionality test. This solution has several advantages. In addition to transparency, it is also consistent with some more widely accepted approaches: we can describe the conflict of those two principles as a specific sort of conflict of competences. According to some authors, if the conflict of competences is based on the conflict of principles, it should be solved by balancing. ${ }^{5}$ My solution can be also seen as part of this broader approach.

\section{THE CONCEPT OF THE SEPARATION OF POWERS AND THE CONTRADICTORY NATURE OF ITS COMPONENTS}

What exactly does the separation of powers mean? Such a question can be surprisingly difficult to give a clear answer to. Fifty years ago, M. J. C. Vile noted that '[a] major problem in an approach to the literature on the doctrine of the separation of powers is that few writers define exactly what they mean by the doctrine, what are its essential elements, and how it relates to other ideas. ${ }^{6}$ Since then, the situation has improved, but some chaos still persists. The word 'power' can already be very ambiguous. ${ }^{7}$ Most authors admit in principle that several separate components are usually combined under the doctrine of the separation of powers. This is sometimes perceived as a consequence of the fact that the idea of separation itself is not sufficient to create a stable political system, but must be combined with other ideas, such as the theory of mixed government, the idea of balance, or the concept of checks and balances. ${ }^{8}$ Such

\footnotetext{
${ }^{5}$ Klatt (2015) 211.

${ }^{6}$ Vile (1998) 13.

${ }^{7}$ Vile (1998) 13.

${ }^{8}$ Vile (1998) 2.
} 
an attitude can be traced not only to M. J. C. Vile, but also to the conclusions of many 19th century authors. ${ }^{9}$ The result of this is a distinction between a pure doctrine that emphasizes separation, and a partial doctrine that is enriched by other elements, especially the already mentioned system of checks and balances. ${ }^{10}$ In fact, nothing like a pure doctrine or a classical system of the separation of powers has ever existed. Such a conviction is rather a simple, powerful and misleading narrative. ${ }^{11}$ Only with the greatest difficulty will we find true proponents of such model concepts throughout history, let alone attempts to implement them in practice.

Which components of the separation of powers are mentioned in the academic literature most frequently? For example, Jeremy Waldron differentiates five principles within the framework, namely: the principle of the separation of powers; the principle of the dispersal of power from which we can derive the prohibition of its concentration in the hands of any person, group or office; the principle of checks and balances; the principle of bicameralism; and the principle of federalism consisting in the division of power between the federal government and the constituencies that represent its states. ${ }^{12}$ A different classification is offered by M. J. C. Vile, who mentions the separation of agencies, the separation of functions, the separation of persons, and the system of checks and balances. ${ }^{13}$ Dimitrios Kyritsis, for the purposes of his theories, also distinguishes between the system of checks and balances and the division of labour. ${ }^{14}$ Finally, Christoph Möllers argues that

[a] closer look at the different traditions will help identify three basic meanings: the first demands an organizational division of different parts of the polity. The second unfolds a precept of alternating checks and balances for all institutions or offices. Finally, the third assigns to the powers specific tasks or functions and prohibits the exercise of these functions through other powers. ${ }^{15}$

We see that all approaches differ in certain ways, but they also have much in common. Some of them, such as Waldron, reflect the specific circumstances in the USA, where they operate with bicameralism and federalism, which, in the context of many other states, have only very limited significance.

I think that in practice we are most often faced with two problems: 1) Who should perform a certain function in a government system ${ }^{16}$, and 2) How much of the exercise of power should be independent or under the control of someone else? In the first context, we are considering whether each function should be exercised by a different state body, whether one body has several functions, or whether one function is to be exercised by several bodies. In the second, we are considering whether to apply the principle of independence or the system of checks and

\footnotetext{
${ }^{9}$ Vile (1998) 4, Fairlie (1923) 393, 405-22.

${ }^{10}$ Barber (2001) 59, 60.

${ }^{11}$ Möllers (2013) 8.

${ }^{12}$ Waldron (2016) 49.

${ }^{13}$ Vile (1998) 17 et seq.

${ }^{14}$ Kyritsis (2017) 40.

${ }^{15}$ Möllers (2013) 43.

${ }^{16}$ To compare this to Kyritsis' definition of the division of labour in the context of the separation of powers, see Kyritsis (2017) 40 .
} 
balances. Both of these problems are mostly largely obscured by a broader consensus on the basic constitutional arrangements. They may manifest themselves, for example, in disputes over the status of various state bodies and officials, their appointment, and appeals.

For our further consideration, it will be crucial that the system of checks and balances and the idea of the independence of power components stand against each other. ${ }^{17}$ We cannot defend the interference of one body by another and, at the same time, defend its independence. These components have a contradictory character, so we can only apply one of them, and which one is an open question, and is based on the criteria we have available to us to make this choice.

It cannot be said that one of the components would have absolute preference, that it would take precedence over the other component in each and every situation. If we were to only emphasize independence, the various state bodies could start living their own lives. We could even endanger the unity of the state. ${ }^{18}$ On the other hand, neither can the system of checks and balances be systematically favoured. Something like that would gradually weaken the division of functions, and this would significantly reduce the effectiveness of the whole system, which requires at least some degree of division of labour. Both components must therefore be given some space. But what is the boundary between their application?

We can assume there is a state where both components are in a balanced relationship. Considering the question of which component we should prefer, we are actually looking for a certain equilibrium. ${ }^{19}$ But are we able to identify this equilibrium with certainty? Jiř́ Baroš, who is optimistic about the concept of the separation of powers, states that we do not have an analytical tool that would allow us to find that out with certainty. ${ }^{20}$ Moreover, the system itself can achieve balance in different states, so if we have to come up with only one concrete solution, we must also ask the question of which is the best balance.

Simple solutions to the problems of selecting components are not available. Attempts to clarify the tripartite concept of the separation of powers by extending it by another branch are not successful. Of course, there is no compelling reason why power has to be divided into just three traditional branches. Although this concept remains alive, it was subject to strong criticism during the 19 th century. ${ }^{21}$ Some authors did not even hesitate to call it a metaphysical construct that is analogous to the theological doctrine of the Holy Trinity. ${ }^{22}$ It was criticized by Frantisek Weyr and Hans Kelsen, ${ }^{23}$ who pointed out the absence of a relevant distinguishing criterion between executive and judicial functions. ${ }^{24}$ According to these authors, there are only two functions of the state - the creation and the application of law. The judiciary and the executive perform the same activity in terms of function, so it is not possible to distinguish them based on

\footnotetext{
${ }^{17}$ Magill (2000) 1127, 1130.

${ }^{18}$ See a recapitulation of such considerations at work in Fairlie (1923) 412-13, 420.

${ }^{19}$ In relation to this, cf. some considerations Kyritsis (2017) 48.

${ }^{20}$ Baroš (2013) 11, 15. Also Magill (2000) 1166.

${ }^{21}$ Cf. Fairlie (1923) 405.

${ }^{22}$ Fairlie (1923) 405. Also, cf. Möllers (2013) 16.

${ }^{23}$ One of the interesting comments made by the reviewer of this text draws attention to the important connection that these authors have to Adolf Merkl. His theory on 'Stufenbau des Rechts' forms the basis of their criticism of the separation of powers.

${ }^{24}$ Weyr (1937) 21. Kelsen (2005) 269.
} 
this criterion. ${ }^{25}$ Thus, we can distinguish these branches of power only by describing their typical activities. The differences between them have a rather historical explanation. ${ }^{26}$ The position of the three branches has historical and political reasons, but theoretically it is not consistent. ${ }^{27}$ The bipartite conception thus took precedence over the tripartite conception, which was also supported by the fact that many older theories distinguished only the legislative and executive component, with the second structured in more detail. ${ }^{28}$ At present, we can encounter different objections that emphasize that the tripartite concept cannot capture the complexity of modern states, especially the diversity of their administrative functions. Such an attitude can be found, for example, in works by authors such as Eoin Carolan ${ }^{29}$ or M. J. C. Vile. ${ }^{30}$

The fact that the development of bureaucracy caused a crisis in the idea of separation of powers and, in particular, its tripartite version, began to be evident in the early 20th century, ${ }^{31}$ but this trend has since strengthened further. Many of the traditional separation of powers theories have overlooked the fact that besides a politically responsible government, there may be an extensive bureaucratic apparatus that can, to a large extent, live its own life. ${ }^{32}$ Frank Vibert points out how unelected bodies (such as independent central banks, various inspection and audit institutions, etc.) are becoming more and more influential in modern democracies. ${ }^{33}$ According to this author, this does not automatically pose a threat to democracy if it forms the fourth branch in the system of separation of powers. ${ }^{34}$ The strong side of such a branch would be to increase people's awareness, which would make them less susceptible to manipulation, especially by politicians. This is something it could do to improve the quality of democracy. ${ }^{35}$ Such a consideration is remarkable, and even if we admit it is correct in its basic outlines, there are still many more institutions today whose inclusion in one of the three traditional branches of power is problematic for various reasons. ${ }^{36}$

These considerations are important because thinking about institutional issues in the traditional scheme may make it impossible to articulate some of the current problems related to the institutional organization of the state. For this reason, it might be more appropriate to stick to the concept of identifying state institutions with specific social interests, as proposed by Eoin Carolan. ${ }^{37}$ But this can hardly lead to the resolution of a conflict between components. No

\footnotetext{
${ }^{25}$ Kelsen (2005) 273.

${ }^{26}$ Kelsen (2005) 275.

${ }^{27} \mathrm{cf}$. Kelsen (2005) 281-82.

${ }^{28}$ Fairlie (1923) 409.

${ }^{29}$ Carolan (2009) 42, 257.

${ }^{30}$ Vile (1998) 16.

${ }^{31}$ Vile (1998) 6-7.

${ }^{32}$ Cf. Fleiner-Gerster (1999) 333.

${ }^{33}$ Vibert (2007) 1, 5.

${ }^{34}$ Vibert (2007) 2.

${ }^{35}$ Vibert (2007) 3, 12-13.

${ }^{36}$ N. W. Barber also presents some of the European Union institutions as their example. Barber (2001) 70.

${ }^{37}$ Carolan (2009) 257.
} 
division of power into the different branches is self-evident, and the question of whether we should prefer their independence or mutual control can be raised independently of it.

All that has been said so far also has significant consequences in the field of legal practice. If we look at how the issues of the separation of powers are solved, for example by the Czech courts, ${ }^{38}$ we find that they proceed arbitrarily. These courts, once again, emphasize components based on independence and separation, ${ }^{39}$ and secondly on the system of checks and balances. ${ }^{40}$ They do not explain the reasons for these choices at all. Czech courts do not have theories that would allow them to judge in each case which of these components should be preferred. Such a decision is entirely up to judges' intuitions. This makes us wonder how much we can trust these intuitions, and the extent to which they are legitimate if the court's decision in a particular case is based on them. Judges' intuitions can also be based on prejudices, or their political opinions and personal sympathies, which should not be considered in their decision-making.

It must be admitted that we cannot entirely exclude intuition from judicial decisions. The world we are part of is too complex to give us a theory that provides clear guidance in all possible situations. However, we must consider when such intuitions are appropriate and when they are not. We should pay special attention to situations in which the absence of more explicit guidance creates space for decision-making on grounds that are obviously illegitimate. The question of which reasons are legitimate and which are not is subtle, and in many cases a clear answer cannot be determined. But everyone agrees that the judge should not decide in favour of the party that has a nicer nose. Personal sympathy should not play a role in his or her decision. People accept being controlled by law, but not by other people and their whims. ${ }^{41}$

The separation of powers thus acquires something of the character of a magical hat. The hat into which, when we put our hand in, we pull out whatever we wish. The contradiction between the emphasis on the independence of an institution and the need to control it through certain checks and balances gives us, in many concrete cases, the opportunity to defend completely contradictory solutions. Of course, concepts of this type have the advantage that they can be easily adopted by very different political regimes. Will they be used over the long term rather than rigid ones which are tied to only one political regime? This does not necessarily have to be the case, because if a political regime is interested in not gradually changing into another, it will try to work with concepts that show little flexibility. In the case of the separation of powers, it will also be limited by its legitimation potential and the by fact that it is traditionally associated with a certain type of ideology. ${ }^{42}$

Anyway, if one can decide in two completely contradictory ways, while pointing to one standard, there is something wrong. Even if we are not able to consistently infer a particular

\footnotetext{
${ }^{38}$ In the Czech Republic, the courts have a strong position. In particular, the institutional design of the Czech Constitutional Court is inspired by Germany and gives this body broad and important powers. In practice, the Constitutional Court thus has the last word in competence conflicts arising from ambiguous provisions of the Constitution.

${ }^{39}$ Czech Republic Constitutional court Judgment of 7 September 2010 n. Pl. ÚS. 4/10 (2016) link 2.

${ }^{40}$ Czech Republic Constitutional court Judgment of 13 January 2015 n. Pl. ÚS 17/14 (2016) link 3. Also cf. the Czech Republic Constitutional court Judgment of 12 September 2007 n. Pl. ÚS 87/06 (2007) link 1.

${ }^{41}$ Waldron (1999) 24.

${ }^{42} \mathrm{~A}$ certain ideological and legitimation framework of the separation of powers can be seen in the fact that for several centuries this doctrine has been associated with the ability to distinguish the institutional structure of a free society from non-free one; cf. Vile (1998) 9-10.
} 
institutional application from a certain principle, it does not relieve us of the obligation to make our decision on the related issues as transparent as possible, and to limit its arbitrariness as much as possible.

\section{THE JUSTIFICATION OF THE SEPARATION OF POWERS AND THE QUESTION OF ITS CONCRETIZATION THROUGH ANOTHER NORMATIVE THESIS}

The justification of the separation of powers is instrumental because it is justified by being a good tool for achieving various goals. Such goals can be very diverse. Thomas Fleiner-Gerster, for example, states that the separation of powers is an essential tool to prevent human error by government officials. ${ }^{43}$ According to Bruce Ackerman, there are three legitimating ideals lying behind it: democracy, professional competence, and the protection and enhancement of fundamental rights. ${ }^{44}$ A considerably longer list is provided by Eoin Carolan, who states that the normative reasons justifying this concept may include that it can

prevent tyranny by ensuring that power is not vested in any single individual or organ; ${ }^{45}$ secure a balance between institutions such that they are capable of supervising each other's actions through a system of checks and balances; ensure law is made in the public interest by establishing a balance of power between institutions, or representative groups; enhance efficiency by giving responsibility for individual tasks to the most appropriate institutional actors; prevent partiality and self-interest by separating the personnel involved in decision-making; ensure objectivity and generality in the creation of laws by separating the tasks of law creation and law enforcement; allow elected and representative officials to supervise the actions of executive officials and call them to account if necessary. ${ }^{46}$

This enumeration not only includes a number of different objectives, but also a number of sub-instruments that we generally consider to be components of the separation of powers. Some of these goals can be considered instrumental to others. For example, guarding the balance between institutions can be seen relatively simply as a means of ensuring liberty. So, we are faced with a large number of goals, which can be structured in several ways. In spite of this, Christopher Möllers's words are true - a theoretical consensus on why a state organization needs the separation of powers has never existed. ${ }^{47}$

Most authors have emphasized the protection of liberty as a goal of the separation of powers. This close relationship can be traced back to Montesquieu, who in his famous work on The Spirit of the Laws emphasized that the purpose of the separation of powers was to prevent tyranny. He

\footnotetext{
${ }^{43}$ Fleiner-Gerster (1999) 337.

${ }^{44}$ Ackerman (2000) 633, 640.

${ }^{45}$ According to classic proponents of the separation of powers theory, such as John Locke or Charles Louis Montesquieu, the separation of powers was meant to prevent the tyranny of the absolute ruler, thereby protecting individual freedom. See Möllers (2013) 41.

${ }^{46}$ Carolan (2009) 27-28.

${ }^{47}$ Möllers (2013) 49.
} 
did not define the notion of tyranny himself, but from the other lines of his work, he conceived of a government that suppressed liberty. ${ }^{48}$ Liberty, of course, is very ambiguous, and is not something we have to think about only in positive and negative senses; we can give it a variety of different, sometimes even contradictory, meanings.

The views of some authors have emphasized that the goal of the doctrine of the separation of powers is the protection of the liberty of the individual, as can be seen in the work of N. W. Barber. ${ }^{49}$ This author argues that the core of the doctrine of the separation of powers is not liberty, but efficiency. ${ }^{50}$ However, this represents a blank concept. If you intend to measure it, you must always consider some other purpose. Being effective means achieving a certain purpose successfully. The fact that this concept alone is not enough to create a version of the separation of powers, is also admitted by Barber. ${ }^{51}$ In his opinion, it needs to be supplemented by a stronger normative thesis in order to generate a sufficiently comprehensive concept that could provide us with some institutional considerations. ${ }^{52}$

We might think that the separation of powers seeks to secure good governance. ${ }^{53}$ Its other possible purposes could easily be subordinated to this very broad goal. The uncertainty of such a very broad goal is not only its strength but also its weakness, since we can have very diverse ideas about what constitutes good government.

As an attempt to resolve the disagreement, a shift toward a higher level of abstraction is sometimes perceived. ${ }^{54}$ All three of the above-mentioned concepts - liberty, efficiency and good government - are seen to be the result of considerable generalizations. However, the separation of powers can hardly be based on such or similar concepts, usually because such concepts are empty, or too ambiguous. Such a statement may lead us to consider whether we should consider the justification of the separation of powers not only in the narrow context of material criteria, but instead, we should focus our attention on procedural criteria, as well. To represent this, we could consider in this context the very thoughtful approach of Christopher Möllers, which is based on the idea of individual and democratic self-determination. ${ }^{55}$ This author considers selfdetermination procedures to be necessary for a legitimate definition and adequate specification of other legitimation standards (e.g. justice, welfare, efficiency); ${ }^{56}$ and this method of legitimation, which is procedural, is compatible with a number of other material justifications. ${ }^{57}$ 'Public authority justifies itself by reference to the self-determination of its subjects. ${ }^{58}$ Möllers' theory represents an interesting shift in comparison with previous approaches. In principle, 
however, he cannot escape the fact that we are unable to justify the ultimate normative reasons behind it. Man develops in his life facing a great paradox - he must have a specific system of values, but is not able to justify why the system should be precisely this one and not another. Even the principle of the separation of powers is not value-neutral, since it is compatible with certain sets of values, but not with others. It cannot be said that the values they deal with are better from an objective, transcendental point of view. Different value bases also have implications for our ideas on how to organize political institutions and what tasks they should fulfil. ${ }^{59}$

Rawls' idea of overlapping consensus can also be applied to the separation of powers. ${ }^{60} \mathrm{We}$ can agree on this principle of institutional arrangements on the basis of different, or even mutually incompatible reasons. This could solve many of the problems associated with establishing the separation of powers. However, significant objections to this idea have been raised, for example by David Miller. ${ }^{61}$ This author also critically relied on pluralist theories of justification, even though he considered them in the specific context of human rights. ${ }^{62}$ He primarily criticized them for conflicts that can arise between different groundings of the concept. ${ }^{63} \mathrm{With}$ this criticism it would be possible to deal with the point that if different groundings lead to conflicts in certain consequences, then there is no real overlapping consensus. But then the question arises as to how often this type of consensus actually occurs, if it is in fact not very rare. The main problem with this idea is that the subject of our consensus is often a very abstract concept under which individual actors can often represent very diverse things and often derive completely contradictory solutions. Just as they differ in groundings, they also differ in the specific applications they derive from the concept. Does such a consensus still have some value?

Against various attempts to find a deeper basis for the separation of powers, and some specific normative ideas in its core, it is possible to raise a number of strong objections. At first glance, approaches that are rather procedural appear to be more acceptable. It is understandable that they do not provide us with material criteria for addressing the specific issues that arise in connection with this concept. After all, their basic ambitions are very different. On the contrary, they slowly guide us to identify a methodological approach that would provide us with solutions that are generally acceptable (or more acceptable) compared to other alternatives, but which will certainly not be absolutely valid.

\section{THE SEPARATION OF POWERS IN LEGAL ARGUMENTATION: THE METHOD OF PROPORTIONALITY AS A LIGHT AT THE END OF THE TUNNEL?}

As has been said several times, the problem is that there are often contradictory components within the separation of powers that allow the choice of contradictory solutions to various related problems. However, if the court justifies its decisions and refers to a principle, its use should not be arbitrary and should in no way give the impression that it is assigned a

\footnotetext{
${ }^{59}$ cf. Barber (2001) 67.

${ }^{60}$ For this idea, see Rawls (2005) 133 et seq.

${ }^{61}$ cf. Miller (2012) 407, 410 et seq.

${ }^{62}$ Miller (2012) 410-11.

${ }^{63}$ Miller (2012) 410-11.
} 
fundamentally different meaning in one case than in another. However, in my opinion, this was done when the Constitutional Court of the Czech Republic in the past dealt with some cases related to the separation of powers. It is not possible without any further clarification to identify the separation of powers with the principle of the separation of agencies in one instance, and in another instance with the system of checks and balances. It is not possible to emphasize that one branch should not interfere with the other on one occasion, and on another occasion underline the positive meaning of intervention, without consistently identifying any relevant differences between individual cases. This is an undesirable situation because it limits the transparent discussion and assessment of the institutional issues to be addressed in individual cases. Transparency is a fundamental starting point for making correct and legitimate decisions. ${ }^{64}$ This situation cannot be eliminated by identifying any basis of the separation of powers, so it is necessary to give the Constitutional Court a methodological tool which would allow it to meet the above-mentioned requirements, at least in the solution of concrete, practical cases.

Such a methodological tool does not have to involve an overly complicated search. It may, in my view, be based on the principle of proportionality. In fact, here we are not dealing with one principle, but with several contradictory principles which serve a similar goal, i.e. to achieve equilibrium and to bring about the best possible government. With independence, the separation of state agencies and the system of checks and balances will work much more correctly if we perceive them as separate principles that can be interconnected for some of the same purposes. Moreover, if the preference for an institution's independence or its control is a question of seeking a certain equilibrium, or even a certain optimal position, what else does the proportionality test ${ }^{65}$ seek to achieve, except the optimal application of conflicting principles? ${ }^{66}$ David M. Beatty's thesis that the principle of proportionality is neutral is also deserving of attention. ${ }^{67}$ This further underlines the suitability of using this methodology.

We can encounter approaches to which we can apply the proportionality test not only to the collision of fundamental rights and public interests, but also to the conflicts of any principles at all. ${ }^{68}$ Using such a methodology in this context can bring more positive results. By using such a methodology, the court is forced to explicitly formulate what collision occurs and compare arguments to support possible solutions.

The tension between the components of the separation of powers could also be understood as a specific type of conflict of competence. ${ }^{69}$ Conflicts of competence may be of various natures and therefore their solution may require the use of different methodologies. There are conflicts

\footnotetext{
${ }^{64}$ The importance of transparency in a democratic system is well emphasized by Aharon Barak: 'However, transparency is a major contribution to the notion of fairness and integrity in the decision-making process. That contribution, in and of itself, is of major value.' Barak (2012) 463.

${ }^{65}$ I understand the proportionality test in Alexy's sense. For its pregnant description, see in Klatt and Meister (2012) 8 et seq.

${ }^{66}$ I completely agree with Klatt who also argues that conflicts of competence, which are constructed as conflicts of principles, should be resolved by balancing. Klatt (2015) 211.

${ }^{67}$ cf. Beatty (2004) 162.

${ }^{68}$ Ondřejek (2012) 95-97.

${ }^{69}$ Matthias Klatt, for example, writes well about the taxonomy of conflicts of competence. Klatt (2015) 199-201.
} 
of rules and conflicts of principles. ${ }^{70}$ They can be solved in several ways. In the case of conflicts of competence, in which principles come into collision, some form of proportionality test is deemed to be appropriate. At least in continental Europe, balancing is considered the usual method by which conflicts of principles are resolved. ${ }^{71}$

Of course, using the methodology described above may have its problematic sides. When we look at the relationships between the various branches, we should be careful, for example, to always compare their idealized or realistic conceptions to each other. We should avoid comparing an idealized idea of one component against the realistic idea of another component (for example an idealized judiciary with a realistic legislature). ${ }^{72}$ However, much more important is the objection that the proportionality test leaves the person who exercises it a great deal of freedom and allows him to apply his subjective attitudes to a certain extent. Such criticism is justified. On the other hand, the projection of subjective attitudes into judicial decision-making can never be avoided and, in comparison with the current state, the use of a judicial test would undoubtedly represent a shift in the right direction that would restrict that arbitrariness.

Despite possible doubts, the application of the principle of proportionality in cases related to the separation of powers would represent a shift toward a better situation than the current one. In addition, proportional reasoning itself is not a specific element of a judge's reasoning but part of general human rationality. It can therefore be applied not only by the courts, but by anyone who will endeavour to do so, including the constituent parties when dealing with the question of what the new constitution should contain. The answer to the problem that has crystallized in the decision-making process of a particular court can therefore be used in a much wider context.

\section{CONCLUSION}

Already John A. Fairlie noted, from the perspective of the first half of the 20th century, that '[a] clean-cut scientific analysis of governmental functions as the basis for a fixed plan of political organization is probably impossible. ${ }^{73}$ This is not surprising. We live in a complex world and the functionality of a political organization is influenced by a number of other factors that we can hardly include under the narrowing concept of the separation of powers. For example, the quality of political culture in a country may have a more influential effect on the day-to-day functioning of the constitutional arrangements than establishing some institutional links. It is

\footnotetext{
${ }^{70}$ cf. Klatt (2015) 211.

${ }^{71}$ The reviewer of this article suggested another solution in his review, which may also be relevant. According to him, in the case of a conflict of competence, we have to decide 'firstly based on the theory of legal unity, secondly on the democratic legitimation of every power aspect, and thirdly on the need for controlled and limited power.' Personally, it seems to me that a solution using proportionality is a simpler procedure. In addition, it has the advantage that the courts use this method in many other cases as well, so that everyone is well acquainted with it. However, listing all the possible advantages and disadvantages of these approaches and comparing them is a task that would extend to a separate article. Therefore, it will not be further elaborated in this article, which will only suggest proportionality as an appropriate solution.

${ }^{72}$ Jeremy Waldron warns us in a similar fashion. See Waldron (1999) 2.

${ }^{73}$ Fairlie (1923) 431.
} 
equally important, however, to realize that the separation of powers was not originally a scientific theory. Montesquieu presented it in his work as a description of the political order in England of his time. ${ }^{74}$ It is not important in these considerations that even this kind of description is not adequate. ${ }^{75}$ Importantly, it was rather a practical guide to serve various practical purposes, most often to prevent tyranny. It has retreated from the attempt to use it in a pure, scientifically advocating form, in favour of focussing on the functioning of a particular state in a particular situation. This is well illustrated by the attitude the founding fathers projected into the US Constitution, which, according to Samuel W. Cooper, did not rely on a leading theory of separation of powers, but was pragmatic. ${ }^{76}$ It is therefore not wrong today to look pragmatically at the issues that are related to the separation of powers. Our institutional arrangement is always the result of various historical contingencies and political compromises.

I do not think there should be a negative feeling about this. This arrangement is, in my opinion, too complex to be fully covered by one theory. Such an effort could also lead to serious externalities. The effort to project ideals into the real world has, at times, led to cruelty and injustice. On the contrary, we should give up trying to build a system of institutional arrangements with the help of certain theories, and we should focus on solving specific problems. A methodological instrument based on the principle of proportionality, which is not linked to the specific arrangement of state bodies, can do this well. It has the potential to allow a highly adaptable system, which can develop freely while minimizing the resulting risks. Moreover, such an approach corresponds to how conflicts of competence based on the collision of principles are to be resolved.

The functionality of the constitutional system is affected by too many factors. They cannot be discarded, nor can they determine their exact impacts. The inability to give absolute answers to individual questions leads us to consider possible alternatives. It is true that no serious alternative to the concept of separation of powers is currently available. Still, we have a duty to limit arbitrariness in court decision-making. This again underlines the importance of proportionality. Finally, if the courts want to differentiate themselves from other branches, should they not be trying to bring arguments into the public space, into the exercise of public authority? Should they not be those who give reasons instead of simply trying to persuade? There is a difference between justification and persuasion, as well as between logic and rhetoric. Reasons cannot often be given by politicians who are subject to election pressure. Should the courts not attempt to do so?

\section{LITERATURE}

Ackerman, B., 'The New Separation of Powers' (2000) 113 Harvard Law Review 633-729.

Barak, A., Proportionality: Constitutional Rights and their Limitations (Cambridge University Press 2012). Barber, N. W., 'Prelude to the Separation of Powers' (2001) 60 Cambridge Law Journal 59-88.

\footnotetext{
${ }^{74}$ Montesquieu (2001) 173 et seq.

${ }^{75}$ Cole (1939) 424, 426.

${ }^{76}$ Cooper (1994) 361, 366.
} 
Baroš, J., 'Dělba moci jako nástroj konstitucionalismu' (The separation of powers as a means of constitutionalism) (2013) 7/22 Jurisprudence 11-17.

Baroš, J., Dufek, P. and Kosař, David, Separation of Powers and Politics in Central Europe (manuscript 2018).

Beatty, D. M., The Ultimate Rule of Law (Oxford University Press 2004).

Carolan, E., The New Separation of Powers: a Theory for the Modern State (Oxford University Press 2009).

Cole, K. C., "Government," "Law," and the Separation of Powers' (1939) 33 The American Political Science Review 424-40.

Cooper, S. W., 'Considering "Power” in Separation of Powers' (1994) 46 Stanford Law Review 361-400.

Fairlie, J. A., 'The Separation of Powers' (1923) 21 Michigan Law Review 393-436.

Fleiner-Gerster, T., Allgemeine Staatslehre (Springer 1999).

Gaus, G. F., and Kukathas, Ch., Handbook of Political Theory (Sage Publications 2004).

Kelsen, H., General Theory of Law \& State (Transaction Publishers 2005).

Klatt, M., 'Balancing Competences: How Institutional Cosmopolitanism Can Manage Jurisdictional Conflicts' (2015) 4 Global Constitutionalism 195-226.

Klatt, M. and Meister, M., The Constitutional Structure of Proportionality (Oxford University Press 2012).

Kyritsis, D., Where Our Protection Lies: Separation of Powers and Constitutional Review (Oxford University Press 2017).

Magill, M. E., 'The Real Separation in Separation of Powers Law' (2000) 86 Virginia Law Review 1127-98.

Miller, D., 'Grounding Human Rights' (2012) 15 Critical Review of International Social and Political Philosophy 407-27.

Möllers, Ch., The Three Branches. A Comparative Model of Separation of Powers (Oxford University Press 2013).

Montesquieu, Ch. L. de Secondat, The Spirit of Laws (Kitchener 2001).

Ondřejek, P., Princip proporcionality a jeho role při interpretaci základních práv a svobod (The principle of proportionality and its role in the interpretation of fundamental rights and freedoms) (Leges 2012).

Rawls, J., Political Liberalism (Columbia University Press 2005).

Vibert, F. The Rise of the Unelected: Democracy and the New Separation of Powers (Cambridge University Press 2007).

Vile, M. J. C., Constitutionalism and the Separation of Powers (Liberty Fund 1998).

Waldron, J., The Dignity of Legislation (Cambridge University Press 1999).

Waldron, J., Political Political Theory: Essays on Institutions (Harvard University Press 2016).

Weyr, F., Československé právo ústavní (Czechoslovak Constitutional Law) (Melantrich 1937).

\section{LINKS}

1. Czech Republic Constitutional court Judgment of 12 September 2007 n. Pl. ÚS 87/06 (2007) <http://nalus. usoud.cz/Search/GetText.aspx?sz=Pl-87-06_1> accessed 19 April 2018.

2. Czech Republic Constitutional court Judgment of 7 September 2010 n. Pl. ÚS. 4/10 (2016) <https://nalus. usoud.cz/Search/ResultDetail.aspx id $=67433 \&$ pos $=1 \& \mathrm{cnt}=3 \&$ typ $=$ result $>$ accessed 31 May 2018.

3. Czech Republic Constitutional court Judgment of 13 January 2015 n. Pl. ÚS 17/14 (2016) <http://nalus.usoud. $\mathrm{cz} /$ Search $/$ ResultDetail.aspx?id $=86828 \& p o s=1 \& \mathrm{cnt}=1 \&$ typ $=$ result $>$ accessed 31 May 2018. 